(1970): 6) OMLRA, T. AND SATO, R.: J. hiol. Chm. 239, 2370(1964): 7) SCHENKMAX, J.B.,

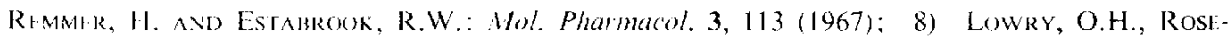

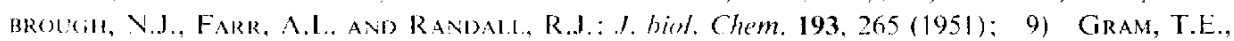

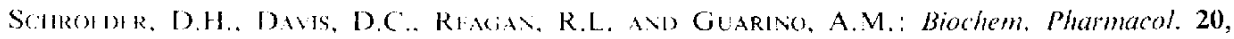

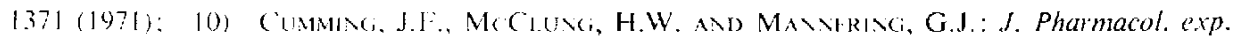
Ther. 178. 595 (1971): 11) GH1111.. J.R. AYM GRAM, T.E.: Microsomes and Drug Oxidations, p. 133, Academic Press. N.Y. and London (1969): 12) S(HEvknan, J.B., Frey, I., Remmer, H. AND EstabroOk, R.W.: Mol. Phamacol. 3, 516 (1967): I3) ReMmer, H. AND Mfrker,

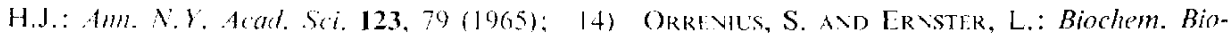
phrs. Res. Commmin. 16. $60(1964)$

\title{
CHANGE IN CATFCHOLAMINF CONTENT OF TETRAHYMENA PYRIFORMIS W DURING GROWTH
}

\author{
Heitaroh IWATA and Kimio KARIYA \\ Depammen of Phamacolog!. Faculty of Pharmaceutical Scionces, \\ Osaka Unisersity. Tomovama. Tovonaka, Osaka, Japan
}

Accepted Junc 22. 1973

In 1966. Janakidevi et al. (1) discovered that the ciliated protozoan, Fotrahyment pryiformis contained catecholamines (CA) and readily converted radioactive tyrosine, phenylalanine and dihydroxyphenylalanine to CA. In our laboratory it was discovered that this protozoan contained the system catalysing the oxidation of biogenic monoamines and damine (2). It was also found that in cultures of Tefrahmena monoamine oxidase activity decreased in the exponential growth phase (EGP) and increased in the stationary growth phase (SGP) (3). The present work was on the change of the endogenous CA level and the rate of conversion of tyrosine w CA during growth of this protozoan.

Tetralymena prriformis $W$ was cultured as reported previously (3). After culture for various periods, cells were treated with $0.4 \mathrm{~N}$ perchloric acid following the procedure of fanakidevi at $a$. (l). CA was isolated by adsorption onto alumina (active neural, Woelm) (4) and was measured fuorometrica!ly, using adrenaline as a standard (5). CA levels during growth of cultures are expressed as lotal CA.

To measure the rate of conversion of tyrosine into $\mathrm{CA}, 50 \mathrm{~m} / \mathrm{Ci} / \mathrm{ml}$ of tyrosine- ${ }^{1:} \mathrm{C}$ (405 $\mathrm{mCi} / \mathrm{mM}$. Daiichi Pure Chemicals) were added to cultures at various stages of growth. After further incubation for $4 \mathrm{hr}$, radioactive CA was extracted as described above. An aliquot wats dissolved in Bray's solution (6) and radioactivity was measured in a liquid scintillation counter.

The CA contents at various times during growth are summarized in Table 1. The content in the early FGP was $0.39 \mathrm{ng} / 10^{9}$ cells, which is in good agreement with the value of Blum of al. (7). The content in the SGP decreased to about one twentieth that in the EGP, therefore the endogenous CA content was higher in rapidly growing Tetrahymena 
TABt. I. Content and radioactivity of catecholanines during growth of cultures of Tetrahymena

\begin{tabular}{|c|c|c|c|c|}
\hline \multirow{2}{*}{$\begin{array}{l}\text { Time } \\
\text { (hr) }\end{array}$} & \multirow[b]{2}{*}{$\begin{array}{l}\text { Cell number } \\
\text { (cells ml) }\end{array}$} & \multicolumn{3}{|c|}{ Catecholamines } \\
\hline & & $\begin{array}{c}\text { Content } \\
\left(\text { (1) } 10^{8} \text { cells) }\right.\end{array}$ & $\begin{array}{l}\text { Radioas } \\
\text { cpm: } 10^{\circ}\end{array}$ & $\begin{array}{l}\text { tivity } \\
\text { cells; }\end{array}$ \\
\hline 24 & $2.1 \times 10^{\prime \prime}$ & 0.39 & $1,178 x$ & $10^{\prime}$ \\
\hline 48 & 17.8 & 0.19 & 180 & $"$ \\
\hline 72 & 79.4 & 0.04 & 20 & " \\
\hline 96 & $112.3 "$ & 0.02 & 3 & $"$ \\
\hline 120 & $121.1 "$ & 0.02 & 3 & " \\
\hline
\end{tabular}

Radioaclive lyrosine was added after various periods of culture after which incubation was continued for $4 \mathrm{hr}$. Total cultivation lime is indicated.

cells than in slowly growing ones. We found previously (8) that. when transferred to fresh medium containing CA, growth of Tomalymen in the FGP was slightly accelerated, while that in the SGP was inhibited. These results indicate that endogenous CA can regulate the growth rate of the protozoan. The possibility that (A regulates growth is supported by the findings of Wurman $a$ al. (9) who stated that during the estrous cycle in rats, the endogenous adrenaline level of the uterus rose significantly in the estrus period, and of Rudzick of at. (10) who reported that stilbesterol caused a parallel increase in the wt. and adrenaline content of the uterus.

The rate of conversion of tyrosine to CA increased abruptly in the eally EGP, whereats it decreased in the SGP. The relationship between the rate of this conversion and the growth of the protozoan cannot be clarified until details of the biochemical propertics of the encyme systems involved in CA synthesis in Torahyment are known.

Il should be mentioned here, that the level of cyclic adenosine $3^{*}, 5^{\circ}$-monophosphate in Terrohyment increased rapidly in the early EGP and later decreased, as was recently observed by the authors, the report of which is now under preparation.

\section{REFERENCES}

1) JANAKIDIVI, K., DEWFY, V.C. AND KIDDER, G.W.: J. hiol. (hem. 241, 2576 (1966): 2) IWATA, H., KariYa, K. AXD OKAMOTO, H.: Exporientia 27, 388 (1971): 3) (WATA, H. AND Karma. K.: Experientia 29. 265 (1973): 4) Avrox, A. and SAYrt. D.: \%. Phamacol, cip. Ther. 138, 260 (1962): 5) VoN Euler, U.S. AND LISHAiko, F.: Acta phixiol, scand. 51, 348 (1961); 6) BRAY, G.A.: Anal. Biochem. 1, 279 (1960); 7) BI.LM, J.J., KIRSHYIR, N. AND Utfley, J.: Mol. Pharmacol. 2. 606 (1966); 8) Iwata, H. Kariya, K. AND Wada, Y.: Japan. J. Phamacol. 23, 751 (1973); 9) Wurtmal, R.J., (HU, E.W. AND Axrlrod, J.: Nature 198, 547 (1963); 10) Rudzik, A.D. And Mill.fr, J.W.: J. Pharmacol, exp. Ther, 138, 88 (1962) 